\title{
Translating Japanese Poetry
}

\section{Matthew Danzinger University of Alberta}

This poem comes from Murō Saisei’s (室生犀星 1889-1962) first book of poetry, Ai no Shishū (愛の詩集 “Collection of Love Poems", 1918). As an early work in the genre of Japanese free verse poetry (自由 詩 jiy $\bar{u}(h i)$, it represents an example of how poets of this time were beginning to write new, vernacular verse as opposed to more traditional forms such as the waka or now globally familiar haiku.

Murō's poetry often deals with loneliness, and in translating "A Poem Written on a Beautiful Night," I aimed to show the way that this manifests in the poem. Contrasts between inside and outside, warm and cold, light and dark, past and present, manifest in many ways throughout the piece. One of the more difficult ones to translate was the change in the first person personal pronoun that Murō uses; at the beginning and end of the poem he uses a more formal one but in the flashback he uses the less formal 僕 boku. English does not carry this distinction, but I translated it as “I, myself' to try and convey the greater sense of interiority that this pronoun might implicate in the original. 
TranscUlturAl, vol. 12.2 (2020), 65-68.

http://ejournals.library.ualberta.ca/index.php/TC

\section{REFERENCES and Further Reading:}

Atsumi, Ikuko, and Graeme Wilson. “The Poetry of Muro Saisei,” Japan Quarterly, vol. 18, no. 3, 1 July 1971, pp. 307-315.

Lento, Takako, Translator. Pioneers of Modern Japanese Poetry. Cornell University East Asia Program, 2019.

Melh, Scott. "The Beginnings of Japanese Free-Verse Poetry and the Dynamics of Cultural Change," Japan Review, no. 28, 2015, pp. 103-132.

Murō, Saisei. Ai no Shishū. Kanjōshisha, 1918. 


\section{A Poem I Wrote on a Beautiful Night}

\section{Murō Saisei}

Matthew Danzinger, translator

In this, my warm room

When it burns it gradually glows

In the light of the beautiful candle

I, poor and hungry, I starve and walk

I think of that cold winter night

That evening, no matter which street I walked

the windows of the houses were all enjoyably bright

There was hot tea

and beautiful, young lives

were brightly, enjoyably being lived

If one lives like that and studies under a quiet light-

I weep to think how much light

the things written there would possess

I, myself, wondered, forever in that bright room

and sitting together in a circle in the evening

will I ever be given that silent harmony again?

Just for one night

I want to feel that happiness

I was thinking about a day where I walked while freezing in the cold

Oh, so time has passed

I am now sitting in a lovely room

There is elegant chintz and other textiles

There are books

Again that pleasant happiness is visiting

Oh, I study 
おま本立僕お寒あひま夜僕どそあ晴美そどああ私美燃私 おたが派はおさあとたのにんこあれしこののるはしての 快あな美にい晚し団はなでしやいに人晚寒貧いるこ 私より更しそ凍ふでん戀永に書てか楽は家どいし蝛との はい紗いしえ幸よとや久光か静にし熱のの冬く燭だ温 勉幸や室てな福いしあのれ営いい空街の飢のんか 強福織に時がをかたん市るな若茶もを夜えあだい 守が物今がらなら平

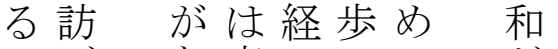

市座己いて が

$\begin{array}{llll}\text { れ } & \text { りてた見 } & \text { 与 } \\ \text { お } & \text { お } & \text { のい } & \text { の }\end{array}$

た た こと视

と思 な
な
を

考て の

なるこ灯狆やや楽歩のかかん室

明ことでていしいこつりに

るとは勉みだくてと总で匂

いか強る生明もをてふ

室とをや活る 考歩

や流しうが少へい

$\approx$ 力

涙ただつたた

て
た

㣻 